\title{
Accuracy of a subcutaneous continuous glucose management system in critically ill patients
}

\author{
L Engelhardt ${ }^{1}$, T Wollersheim ${ }^{1 *}$, J Pachulla ${ }^{1}$, R Mörgeli ${ }^{1}$, F Balzer ${ }^{1}$, K Mai $^{2,3}$, S Weber-Carstens ${ }^{1,3}$ \\ From ESICM LIVES 2015 \\ Berlin, Germany. 3-7 October 2015
}

\section{Introduction}

Continuous glucose management (CGM) has not yet been implemented to daily routine in the intensive care unit (ICU) setting. CGM systems aim to improve glycemic control, and consequently patient outcome.

\section{Objectives}

The main purpose of this study was to evaluate accuracy of the subcutaneous Medtronic Sentrino ${ }^{\circledR}$ CGM system in critically ill patients.

\section{Methods}

Inclusion criteria were an expected length of stay in the ICU of at least $72 \mathrm{~h}$, age $\geq 18$ years, and availability of informed consent given by patient or legal proxy. Sensors were inserted into subcutaneous tissue of the patient's thigh, quantifying interstitial glucose concentration based on glucose oxidase reaction. Measurements were collected for up to $72 \mathrm{~h}$, while calibrations took place every eight hours, as recommended by the manufacturer. Arterial blood glucose (BG) values determined by blood gas analyzer Radiometer ABL800 were used as reference. Accuracy was illustrated in Clarke-error-grid and Bland-AltmanPlot. Non-parametric tests were performed (MannWhitney U Test and Spearman's Correlation). Ethic vote Charité EA2/095/14.

\section{Results}

544 paired glucose values were generated from 32 sensors in 20 critically ill patients. Mean absolute relative difference (MARD) was $15.2 \%$ (95\% CI 13.5\%-17.0\%). 60.7\% of sensor data deviated $\leq 12.5 \%$ from reference BG (or were within $\pm 10 \mathrm{mg} / \mathrm{dl}$ for readings $<100 \mathrm{mg} / \mathrm{dl}$ ), while $76.7 \%$ were within $20 \%$ of the reference. Clarke-error-grid is

${ }^{1}$ Charité Universitätsmedizin Berlin, Campus Virchow \& Campus Mitte, Anesthesiology and Operative Intensive Care Medicine, Berlin, Germany Full list of author information is available at the end of the article represented in Figure 1. In the Bland-Altman-Plot (graph not shown) mean bias was $+1.55 \mathrm{mg} / \mathrm{dl}$ and limits of agreement were $+65.7 \mathrm{mg} / \mathrm{dl}$ and $-62.6 \mathrm{mg} / \mathrm{dl}$ (mean bias \pm 1.96x standard deviation (SD)). We identified that the BG variability, analyzed in $\mathrm{SD}$, is significantly associated with CGM accuracy (Figure 2). Confirming these finding, SD per patient was positively correlated with MARD per patient $\left(\mathrm{k}=0.68, \mathrm{p}=.001, \mathrm{n}=20, \mathrm{R}^{2}=0.345\right.$, graph not shown). Furthermore, MARD from the CGM devices was significantly higher when BG was $>180 \mathrm{mg} / \mathrm{dl}(\mathrm{p}=.038)$ or $<80 \mathrm{mg} / \mathrm{dl}(\mathrm{p}<.001)$, as compared to the reference range of $80 \mathrm{mg} / \mathrm{dl}-180 \mathrm{mg} / \mathrm{dl}$ (graph not shown).

\section{Conclusions}

In our patients, subcutaneous CGM accuracy does not fulfill criteria specified in the consensus recommendations of the expert meeting published in 2013 ([1]). Accuracy deteriorated in patients with high blood glucose variability,

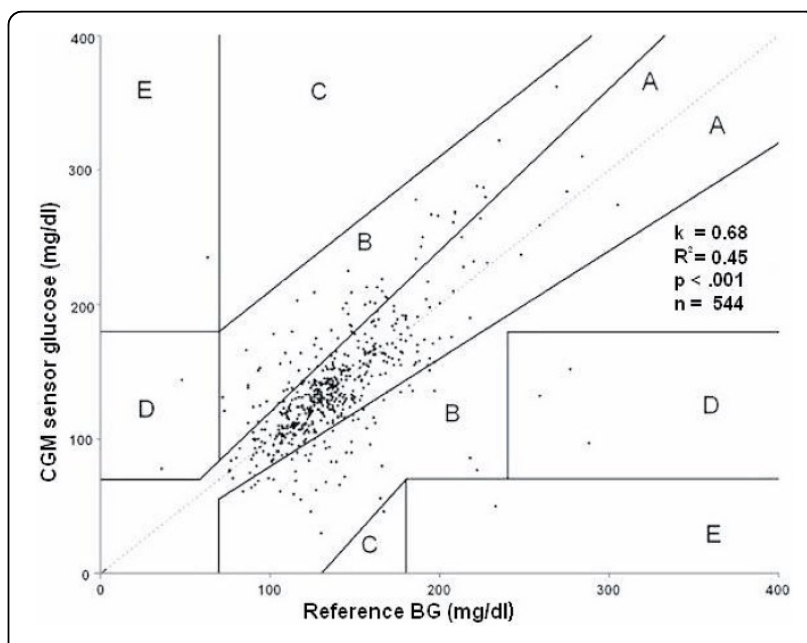

Figure 1 Clarke-Error-Grid showing 544 values. Distribution: A $=76.7 \%, \mathrm{~B}=21.9 \%, \mathrm{C}-.2 \%, \mathrm{D}=0.9 \%, \mathrm{E}=0.4 \%$. 


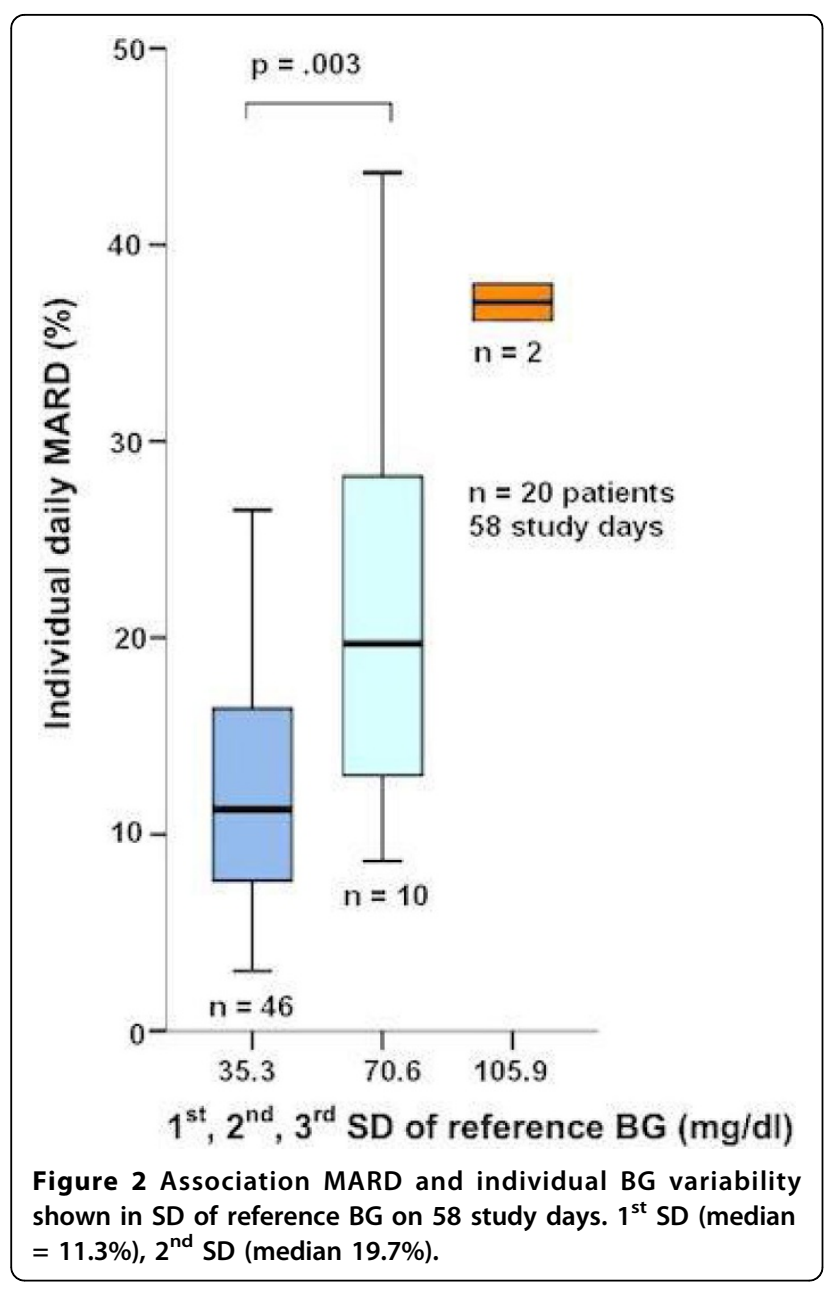

as well as in the hypo- and hyperglycemic range. Following our data, we cannot recommend a clinical use of the investigated device.

\section{Grant Acknowledgment}

Preliminary study within ECCRN research award for clinical nutrion 2013.

\section{Authors' details}

${ }^{1}$ Charité Universitätsmedizin Berlin, Campus Virchow \& Campus Mitte, Anesthesiology and Operative Intensive Care Medicine, Berlin, Germany. ${ }^{2}$ Charité Universitätsmedizin Berlin, Department of Endocrinology, Diabetes and Nutrition, Berlin, Germany. ${ }^{3}$ Berlin Institute of Health $(\mathrm{BIH})$, Max Delbrück Center for Molecular Medicine and Charité Universitätsmedizin Berlin, Berlin, Germany.

Published: 1 October 2015

\section{Reference}

1. Finfer S, Wernerman J, Preiser J-C, Cass T, Desaive T, Hovorka R, et al: Clinical review: consensus recommendations on measurement of blood glucose and reporting glycemic control in critically ill adults. Crit Care 2013, 17(3):229.
doi:10.1186/2197-425X-3-S1-A291

Cite this article as: Engelhardt et al:: Accuracy of a subcutaneous continuous glucose management system in critically ill patients. Intensive Care Medicine Experimental 2015 3(Suppl 1):A291.

\section{Submit your manuscript to a SpringerOpen ${ }^{\circ}$ journal and benefit from:}

- Convenient online submission

- Rigorous peer review

- Immediate publication on acceptance

- Open access: articles freely available online

- High visibility within the field

- Retaining the copyright to your article

Submit your next manuscript at $>$ springeropen.com 